\title{
The Effect of the Binder Phase and Sintering Temperature on the Properties of Spark Plasma Sintering WC-Co Cemented Carbides
}

\author{
Tomasz Dembiczak ${ }^{1}$, Zbigniew Balaga ${ }^{2}$, Michal Opydo ${ }^{2}$, Robert Kruzel ${ }^{3}$, Dariusz Garbiec ${ }^{4}$, Marcin Dyner \\ ${ }^{1}$ Faculty of Science and Technology, Jan Dlugosz University in Czestochowa. 13/15 Armii Krajowej Street, 42 - \\ 200 Czestochowa. Poland. E-mail: t.dembiczak@ujd.edu.pl \\ ${ }^{2}$ Faculty of Production Engineering and Materials Technology, Czestochowa University of Technology. 19 Armii \\ Krajowej Street, 42-200 Czestochowa. Poland. E-mail: balaga.zbigniew@wip.pcz.pl, opydo.michal@wip.pcz.pl \\ ${ }^{3}$ Faculty of Civil Engineering, Czestochowa University of Technology. 3 Akademicka Street, 42-200 Czestochowa. \\ Poland. E-mail: kruzel@bud.pcz.pl \\ 4Lukasiewicz Research Network, Metal Forming Institute. 14 Jana Pawla II Street, 61-139 Poznan. Poland. E-mail: \\ dariusz.garbiec@inop.poznan.pl \\ ${ }^{5}$ Chirmed, Polish producer of surgical and dental instruments. 8A Mstowska Street, 42-240 Rudniki. Poland. E- \\ mail: m.dyner@chirmed.pl
}

Cemented carbides belong to one of the most important groups of tool materials, whose percentage among all other materials used for cutting tools has reached about $50 \%$ in the global industry. Powder metallurgy methods have been used to produce cemented carbides, of which spark plasma sintering (SPS) is considered highly prospective. This paper presents the results of preliminary research concerning the effect of the fraction of the binder phase and sintering temperature on the microstructure, density, hardness and resistance to brittle fracture of cemented carbides produced by spark plasma sintering. The test materials were WC powder with a purity of min. $99.5 \%$ and Co powder with a purity of min. 99.8\%. The obtained mixtures (WC-3Co, WC-6Co and WC-9Co) were sintered using the SPS method at $1300^{\circ} \mathrm{C}, 1350^{\circ} \mathrm{C}$ and $1400^{\circ} \mathrm{C}$. The heating rate was $400^{\circ} \mathrm{C} / \mathrm{min}$. The pressing load was $80 \mathrm{MPa}$. Density measurements were carried out using the Archimedes method in accordance with PN-EN ISO 3369:2010, while hardness measurements, using the Vickers' method, were performed in accordance with PN-EN 23878:1996. Resistance to brittle fracture was determined based on the measurement of the length of cracks formed on the corners of the indentation. The observations of the microstructure and analysis of chemical composition were carried out using the scanning electron microscope. The phase composition of the obtained materials was determined by means of X-ray diffractometry.

Keywords: cemented carbides, plasma spark sintering, microstructure, mechanical properties

\section{Introdution}

Sintered components offer opportunities for the development of creative and cost-effective design solutions. The manufacture of structural components from powders has proved in many cases to be more competitive compared to other manufacturing technologies, especially for components with complex geometric shapes. The production process involves the compaction of the powder material and the subsequent sintering process. Today, more than 40 million elements are produced every day in the world using powder metallurgy techniques, which are used in numerous industries.

Conventional WC-Co carbides continue to be a common tool material. They represent more than half of the current machining tools. Cemented carbides are characterized by high hardness, high resistance to abrasive wear, good thermal and electrical conductivity and thermal stability at elevated temperature $[1,2]$.
Cobalt, most commonly used as a matrix, has very good wettability to carbides, conducts heat very well and has a high melting point of $1494^{\circ} \mathrm{C}$. Carbides are hard and wear-resistant materials and have quite good strength properties [3]. Cemented carbides are produced by powder metallurgy using free sintering [4], hot pressing (HP) [5], isostatic hot pressing (HIP) [6], microwave sintering [7], high-frequency induction sintering [8] or spark plasma sintering (SPS) [9-13], which were described in detail in the paper [14].

\section{Experimental}

The test material was WC powder with a purity of min. $99.5 \%$ and Co powder with a purity of min. $99.8 \%$, provided by KAMB Import-Export (Poland). The powders were mixed in a Turbula-type mixer to obtain a mixture of powders with Co of 3\%, 6\% and $9 \%$ by weight. The obtained WC-3Co, WC-6Co and WC-9Co mixtures were sintered using the SPS 
method with the HP D 25-3 device (FCT Systeme $\mathrm{GmbH}$ ) at temperatures of $1300^{\circ} \mathrm{C}, 1350^{\circ} \mathrm{C}$ and $1400^{\circ} \mathrm{C}$ at a pressing load of $80 \mathrm{MPa}$. The heating rate was $400^{\circ} \mathrm{C} / \mathrm{min}$. Sinters with dimensions of $\phi 20 \times 3$ $\mathrm{mm}$ were produced by the sintering processes. The test specimens were cut out with the wire electrical discharge machining (WEDM).

The examinations of the surface morphology of powder particles were conducted with the use of TESCAN scanning electron microscope. The analysis of the microstructure of the produced sinters was carried out on the non-etched metalographic cross-sections using JEOL JSM - 6610LV scanning electron microscope equipped with EDS analyser. Apparent density measurements were carried out using the hydrostatic weighing method in accordance with PN-EN ISO 3369: 2010 by means WPS 750/C/1 (Radwag) laboratory scale. The hardness measurements were conducted using the Vickers hardness test in accordance with PN-EN ISO 6507-1: 2007 using the FM-700 (Future Tech) hardness tester at a load of $294.2 \mathrm{~N}$. Resistance to brittle fracture (critical stress intensity coefficient $\mathrm{K}_{\mathrm{Ic}}$ ) was determined using the relation (1), where HV30 is the hardness measured under load of $294.2 \mathrm{~N}$, and $\Sigma \mathrm{l}$ is the sum of lengths of the cracks formed in the corners of the indentations [15].

$$
K_{k}=0,15 \cdot \sqrt{\frac{H V 30}{\sum l}}
$$

Where:

HV30- hardness measured under load od $294.2 \mathrm{~N}$,

$\Sigma$ l- sum of lengths of the cracks in the corners of the indentations.

The analysis of phase composition was carried out by X-ray diffraction method using SEIFERT XRD 3003 T-T X-ray diffractometer with a cobalt anode tube.

\section{Results and discussion}

Fig. shows the morphology of the powder particles of the initial WC and Co. The disclosed WC and Co powder particles consist of very fine particles with a spongy structure. Sinters were produced using the spark plasma sintering from mixtures of powders WC3Co, WC-6Co and WC-9Co, which were subjected to density and hardness measurements. The mean results are presented in Figs $2 \div 4$.

Density is one of the most important characteristics of sintered materials. The analysis of the research results showed that an increase in the fraction of the cobalt matrix and temperature of the sintering process leads to an increase in relative density. The maximum value of relative density was $98.1 \%$ for 9 Co sinter produced at $1400^{\circ} \mathrm{C}$ (Fig. 2b). The produced carbides are characterized by hardness from 1664 to 1939 HV30. It was demonstrated that the hardness of cemented carbides at particular temperatures decreases with the increasing fraction of the soft and plastic Co matrix.

This phenomenon is most likely related to the growth of WC grains, which, according to the literature data, may result from an increase in the sintering temperature and is consistent with the Hall-Petch law [14].

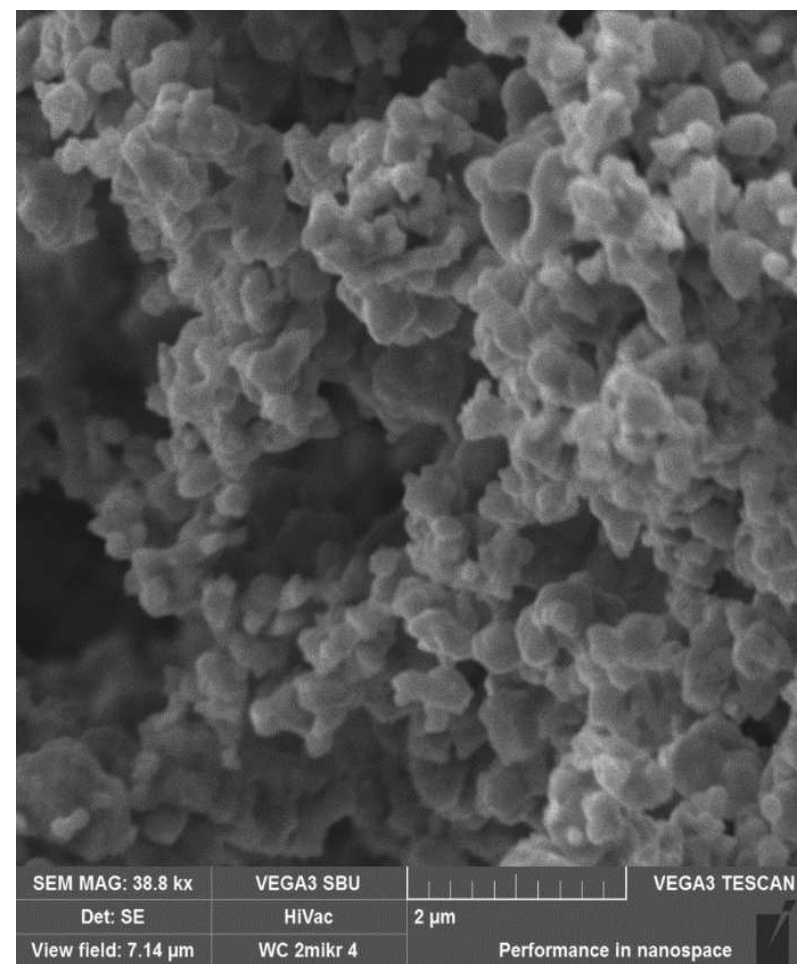

a)

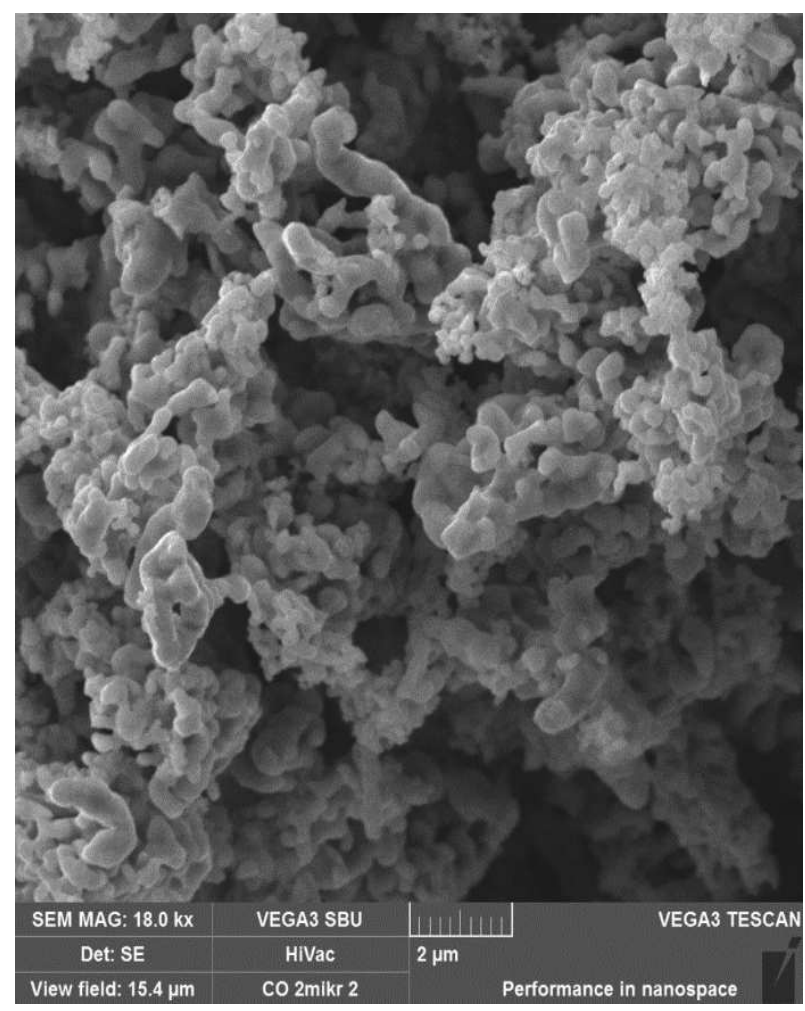

b)

Fig.1 Morphology of powders: a) WC, b) Co 


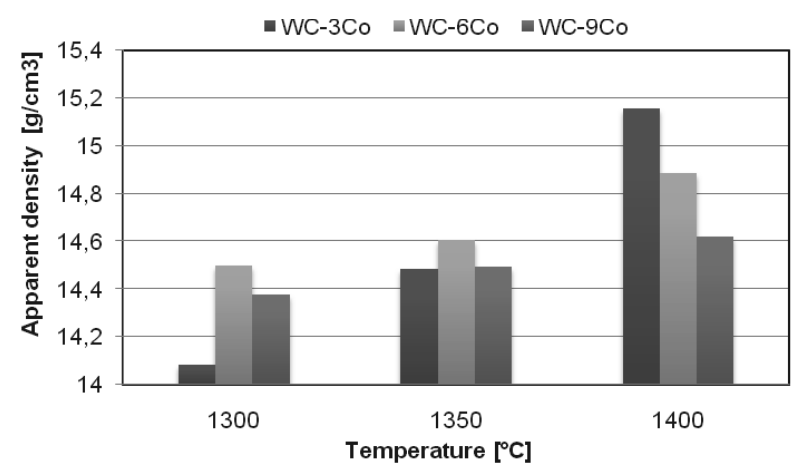

a)

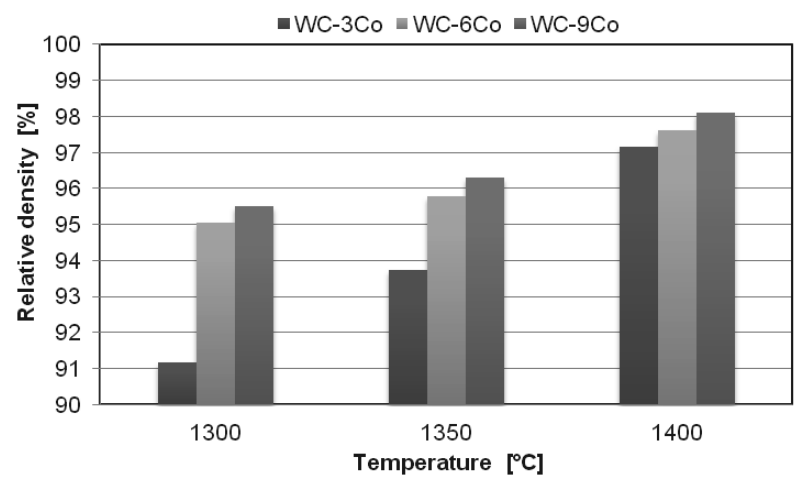

b)

Fig. 2 Measurements of the density of WC-3Co, WC-6Co and WC-9Co specimens: a) apparent density of sinters, b) relative density of sinters

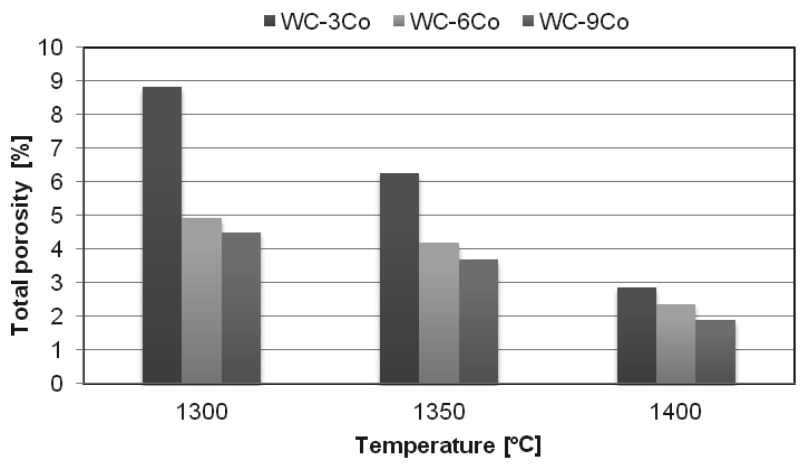

Fig. 3 Measurements of sinter porosity: WC-3Co, WC-6Co, WC-9Co

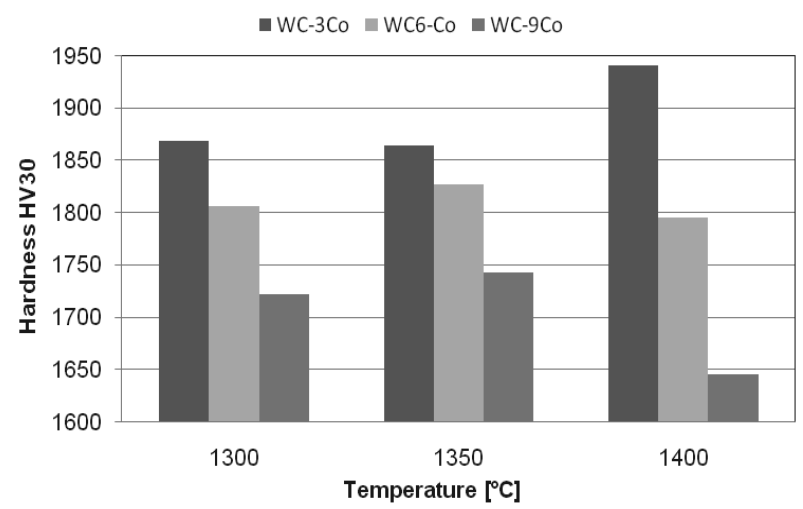

a)

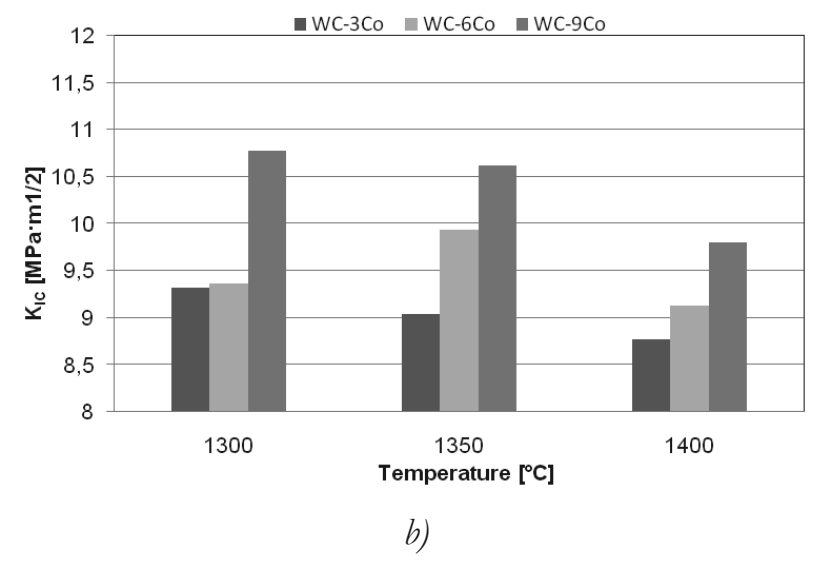

Fig. 4 Measurements of mechanical properties: a) Vickers bardness, b) resistance to brittle fracture

This means that WC-3Co, produced at a sintering temperature of $1400^{\circ} \mathrm{C}$, had the greatest hardness of 1939 HV30, whereas and the lowest hardness of 1644 HV30 was found for WC-9Co carbide produced at $1400^{\circ} \mathrm{C}$. Fig. 5 shows the microstructure of an example of WC-3Co sintered carbide produced at sintering temperatures of $1300^{\circ} \mathrm{C}, 1350^{\circ} \mathrm{C}$ and $1400^{\circ} \mathrm{C}$.

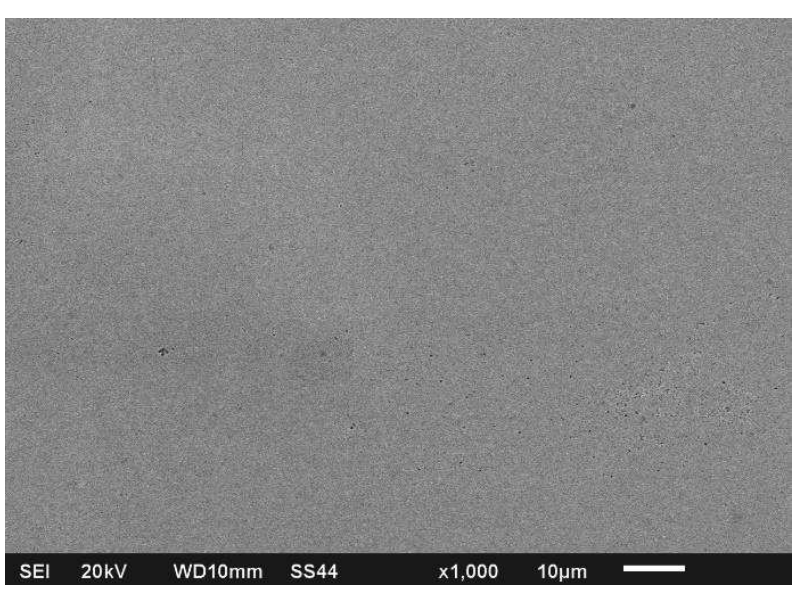

a)

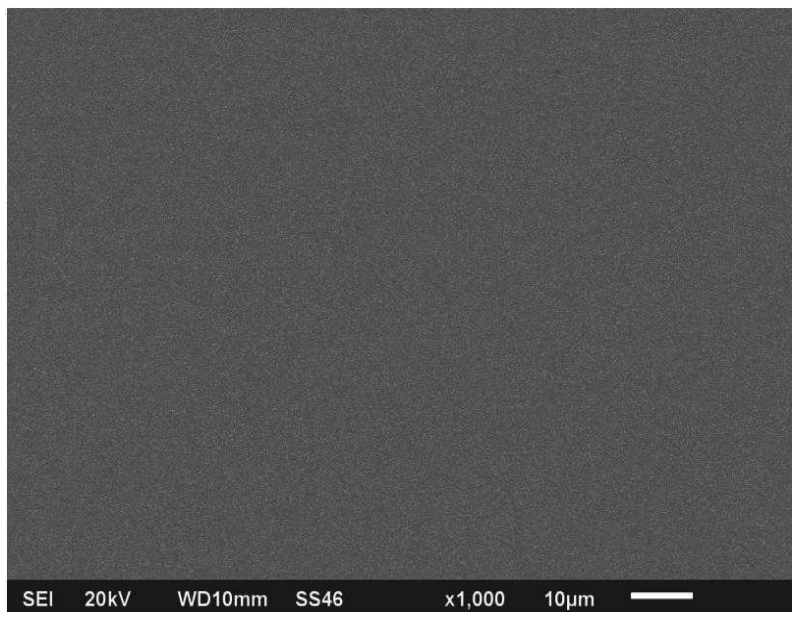

b) 


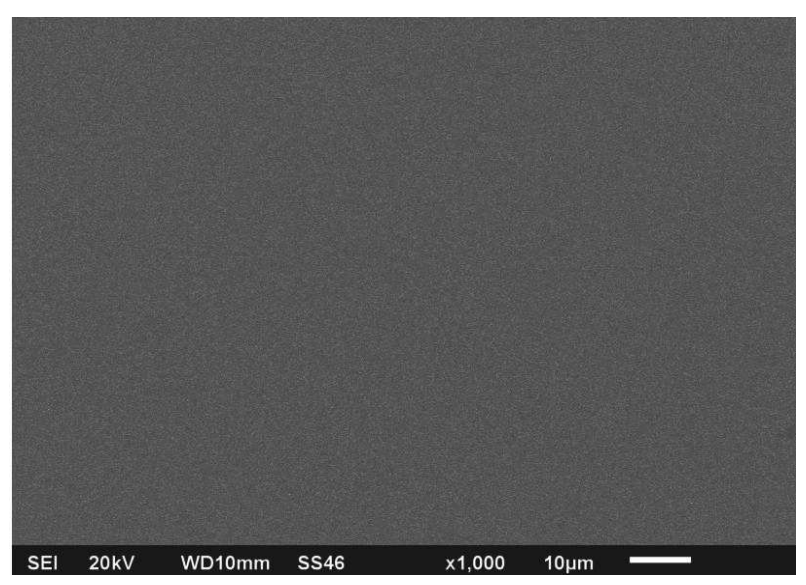

c)

Fig.5 SEM images for $W C-3 C$ o for different sintering temperatures: a) $\mathrm{T}=1300^{\circ} \mathrm{C}$; b) $\mathrm{T}=1350^{\circ} \mathrm{C}$; c) $\mathrm{T}=1400^{\circ} \mathrm{C}$
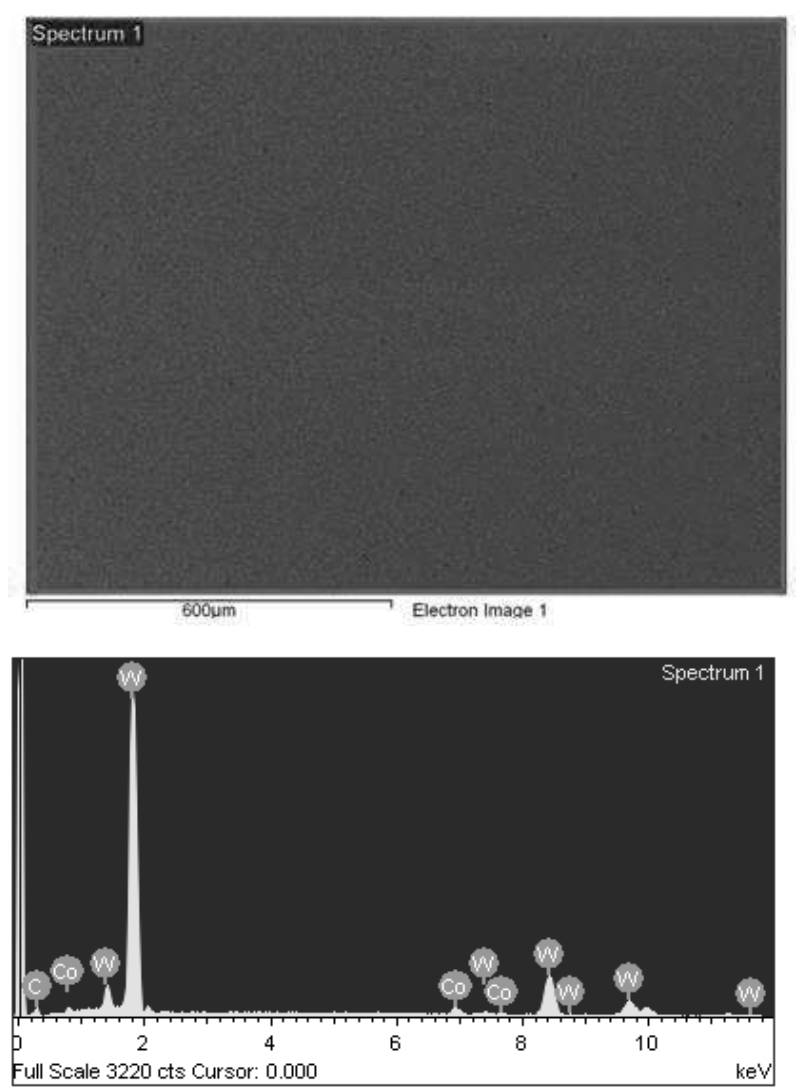

Fig. 6 Example of the analysis of the chemical composition of the $\mathrm{WC}-3 \mathrm{Co}$ sinter produced at $1300^{\circ} \mathrm{C}$

Sinters obtained using the SPS method were characterized by total porosity (Fig. 3) ranging from $1.91 \div 2.85 \%$ at a sintering temperature of $1400^{\circ} \mathrm{C}$, from $3.69 \div 6.25 \%$ at $1350^{\circ} \mathrm{C}$, and $4.48 \div 8.83 \%$ at $1300^{\circ} \mathrm{C}$.

The microscopic images (Fig. 5) confirm the results obtained for porosity. No pores were found in the microphotographs.

The fraction of the binder phase and the sintering temperature have an effect on the total porosity of the obtained WC-3Co, WC-6Co and WC-9Co sinters, influencing the relative density (Fig. 2b), which is one of the most important parameters in the sintering process.

Figures 6 and 7 show an example of the analysis of chemical composition using scanning microscopy of the WC-3Co sinter at $1300^{\circ} \mathrm{C}$.

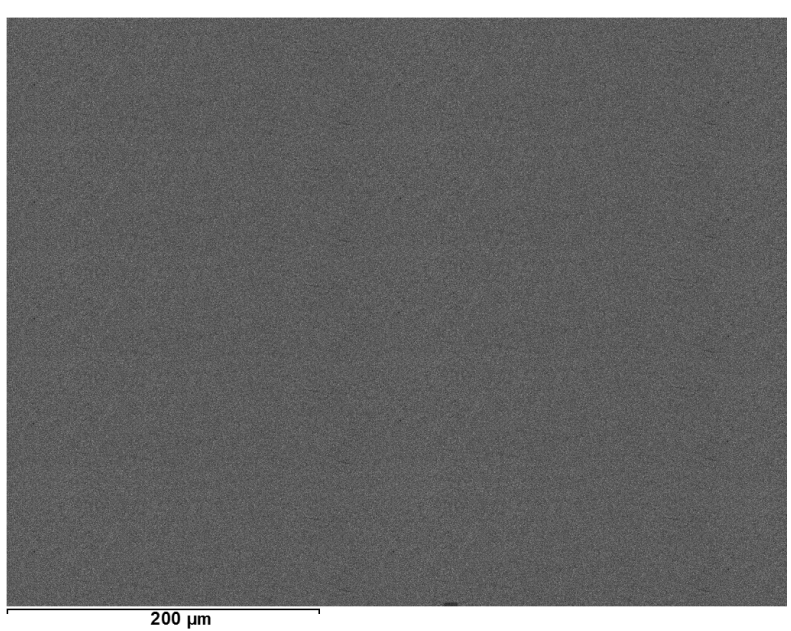

a)

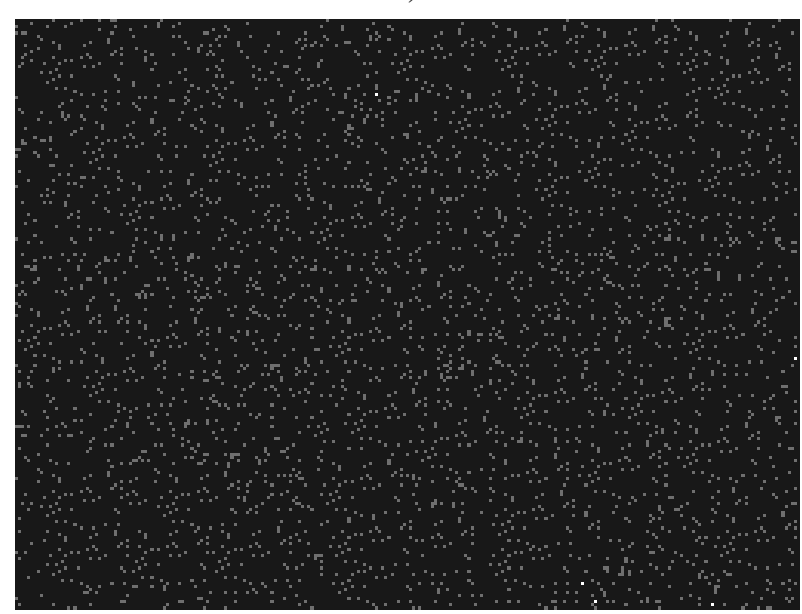

$200 \mu \mathrm{m}$

b)

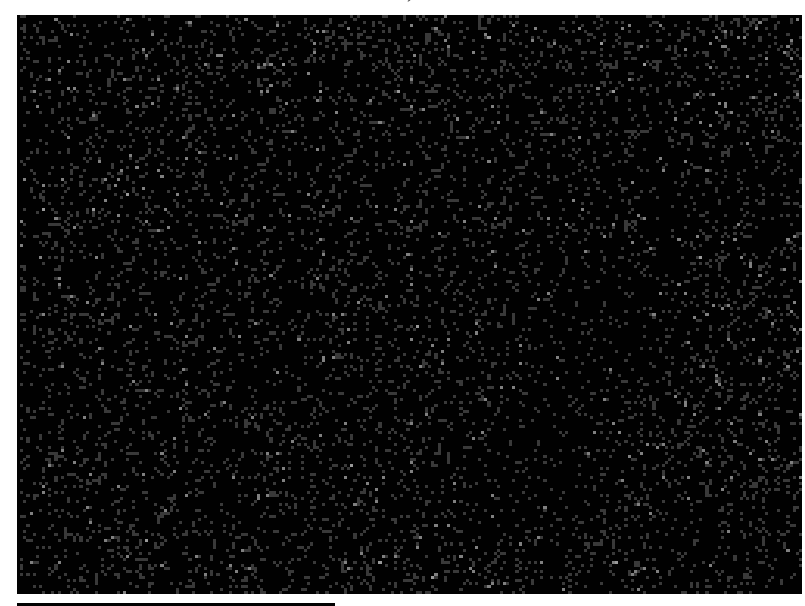

$200 \mu \mathrm{m}$

c) 


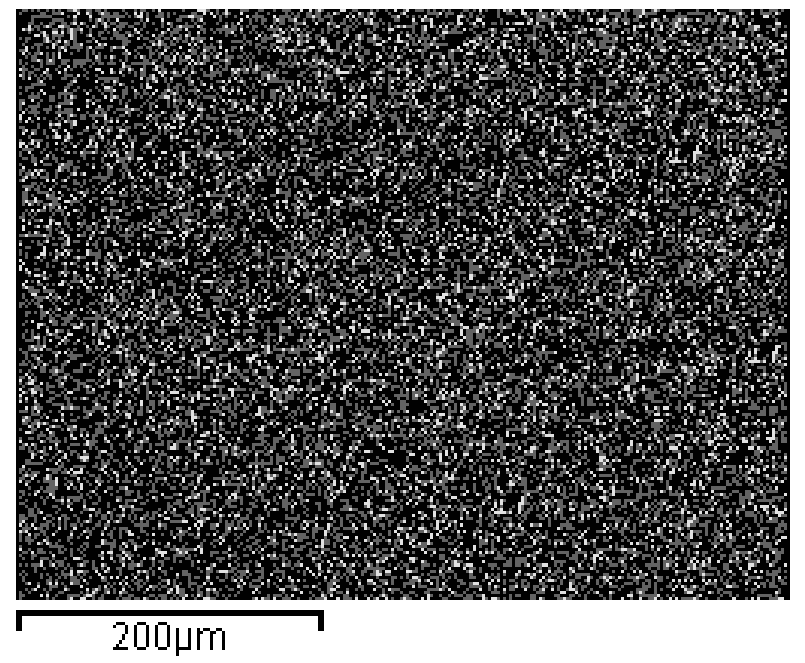

d)

Fig. 7 Example of a map of the distribution of sinter elements of WC-3Co produced at $1300^{\circ} \mathrm{C}$ : (a) microstructure;

(b) carbon; (c) cobalt (d) tungsten

Based on the chemical analysis performed using a scanning microscope for an example of the $\mathrm{WC}-3 \mathrm{Co}$ sinter obtained at a sintering temperature of $1300^{\circ} \mathrm{C}$ revealed carbon content of $11.47 \%$ by weight, cobalt content of $2.99 \%$ by weight and tungsten content of $85.54 \%$ by weight. Maps of the distribution of elements obtained using the EDS method (Fig. 7) did not show any significant traces of element segregation, which is the evidence of the correct mixing time for the powders prepared for the sintering process.

Figure 8 shows $\mathrm{X}$-ray diffractograms of sinters with $3 \%$ wt. of $\mathrm{Co}$ at $1300^{\circ} \mathrm{C}, 1350^{\circ} \mathrm{C}$ and $1400^{\circ} \mathrm{C}$.

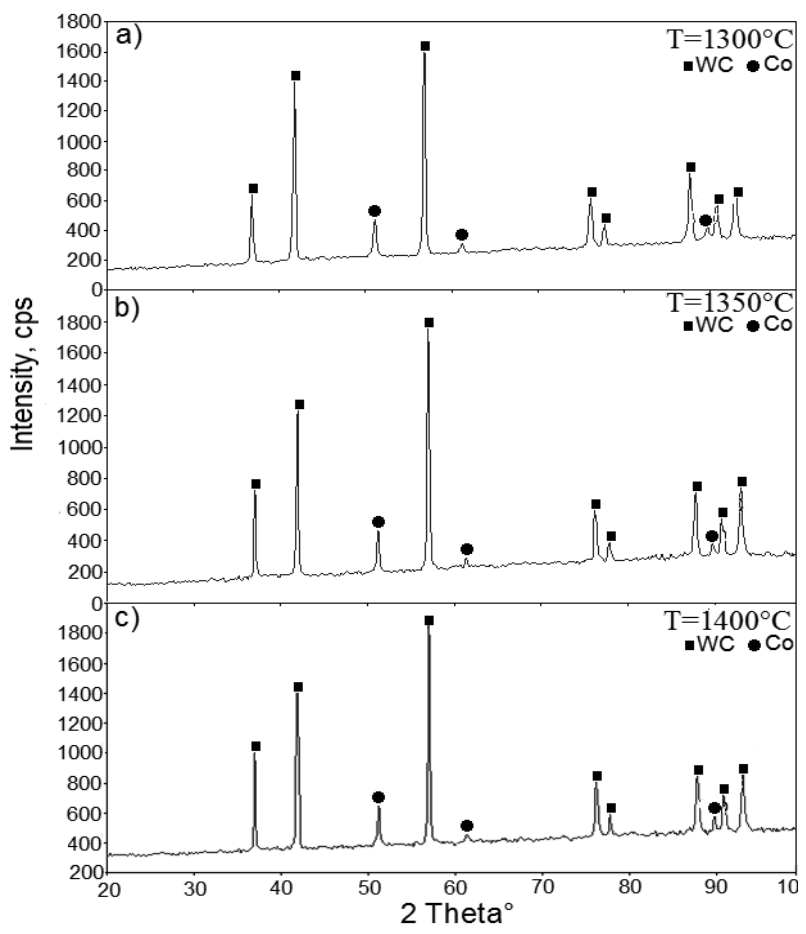

Fig. 8 Diffractograms of WC-3Co sinters obtained by means of the SPS method
The X-ray examinations showed the presence of tungsten carbide and cobalt in the structure, i.e. two phases which formed the mixtures of powders used in the sintering process.

Based on the diffractograms, however, no effect of sintering process temperature on the occurrence of new phases that may be formed as a result of the reaction of tungsten carbide with cobalt was found.

\section{Conclusion}

Preliminary research of the effect of the fraction of the Co binder phase and sintering temperature on the physical and mechanical properties of cemented carbides allowed for characterization of the produced WC-Co sinters with the weight fractions of $3 \%, 6 \%$ and $9 \% \mathrm{Co}$. The materials tested were produced using the SPS method, at sintering temperatures of $1300^{\circ} \mathrm{C}$, $1350^{\circ} \mathrm{C}$ and $1400^{\circ} \mathrm{C}$, while the pressing load was 80 $\mathrm{MPa}$.

The study found that increasing the fraction of the binder phase in the form of cobalt causes a decrease in the HV30 hardness at each sintering temperature.

The greatest effect of the binding matrix (Co) on the HV30 hardness was found in the case of sinters at $1400^{\circ} \mathrm{C}$. The hardness results obtained ranged from 1936 HV30 for sinters with 3\%Co to 1644 HV30 for sinters with $9 \%$ Co.

The determined coefficients of resistance to brittle fracture $\mathrm{K}_{\mathrm{Ic}}$ showed the opposite tendency to hardness. The highest resistance to brittle fracture was observed for sintering with $9 \% \mathrm{Co}$. Furthermore, the effect of sintering temperature on the $\mathrm{K}_{\mathrm{Ic}}$ value was also observed. The sinters with $3 \% \mathrm{Co}, 6 \% \mathrm{Co}$ and $9 \% \mathrm{Co}$ obtained at $1400^{\circ} \mathrm{C}$ had the highest coefficient of resistance to brittle fracture.

The analysis of the obtained results revealed that sinters produced at $1350^{\circ} \mathrm{C}$ are characterized by an optimal combination of properties such as hardness and resistance to brittle fracture, even though the porosity is slightly higher compared to that of sinters produced at $1400^{\circ} \mathrm{C}$.

\section{References}

[1] NOWACKI J. (2005). Spiekane metale $i$ kompozyty z osnowa metaliczna, Wydawnictwo Naukowo-Techniczne, Warszawa.

[2] RUTKOWSKI W.(1977). Projektowanie $i$ wlaściwości wyrobów spiekanych zproszkón i w tókien, Państowe Wydawnictwo Naukowe, Warszawa.

[3] CICHOSZ P. (2006). Narzedzia Skrawajace, pp. 33-42. Wydawnictwo Naukowo-Techniczne, Warszawa.

[4] ARATO P., L. BARTHA, R. PORAT, S. BERGER, A. ROSEN. (1998). Solid or liquid 
phase sintering of nanocrystalline $\mathrm{WC} \backslash \mathrm{Co}$ hardmetals. Nanostructured Materials, Vol. 10, pp. $245-255$

[5] JIA CH., L. SUN, H. TANG, X. QU. (2007). Hot pressing of nanometer WC-Co powder. International Journal of Refractory Metals and Hard Materials, Vol. 25, pp.53-56.

[6] WEI CH., X. SONG, S. ZHAO, L. ZHANG, W. LIU. (2010). In-situ synthesis of WC-Co composite powder and densification by sinterHIP. International Journal of Refractory Metals and Hard Materials, Vol 28, pp. 567-571.

[7] BAO R., J. YI, Y. PENG, H. ZHANG, A. LI. (2012). Decarburization and improvement of ultra fine straight WC-8Co sintered via microwave sintering. Transactions of Nonferrous Metals Society of China, Vol. 22, pp. 853-857.

[8] BAO R., J. YI. (2013). Effect of sintering atmosphere on microwave prepared WC8wt.\% \%o cemented carbide. International Journal of Refractory Metals and Hard Materials, Vol. 41, pp. 315-321.

[9] KIM H., D. OH, I. SHON. (2004). Sintering of nanophase WC-15vol.\%Co hard metals by rapid sintering process. International Journal of Refractory Metals and Hard Materials, Vol. 22, pp. 197-203.

[10] KIM H., D. OH, J. GUOJIAN, I. SHON. (2004). Synthesis of WC and dense WC-5 vol. \% Co hard materials by high-frequency induction heated combustion. Materials Science and Engineering: A 368, pp. 10-17.

[11] KNAISLOVA A, NOVAK P, PRŮŠA F, JAROMIR KOPEČEK J. (2018). Microstructure of TiAl15Si15 Alloy Prepared by Powder Metallurgy. Manufacturing Technology, Vol. 18, No.4, pp. 593-596.

[12] KNAISLOVA A, KUČERA1 D, MICHALCOVA A, MAREK I, CYGAN S, JAWORSKA L. (2018). Microstructure of AlCrFeSi Alloys Prepared by High-Pressure Spark Plasma Sintering. Manufacturing Technology, Vol. 18, No.5, pp. 753-757.

[13] KUČERA V, DALIBOR V. (2018). Processing of $\mathrm{Al}-\mathrm{Si}$ Waste Contaminated with Iron by Powder Metallurgy. Manufacturing Technology, Vol. 18, No.1, pp. 60-65.

[14] GARBIEC D. (2015). Iskrowe spiekanie plazmowe (SPS): teoria i praktyka. Insynieria Materiatowa Vol. 2, pp. 60-64.

[15] SCHUBERT W.D., H. NEUMEISTER, G. KINGER, B. LUX. (1998). Hardness to toughness relationship of finegraded WC-Co hardmetals. International Journal of Refractory Metals and Hard Materials, Vol. 16, pp. 133-142.

[16] NITKIEWICZ Z., IWASZKO J. (2003). Materialy i uyroby spiekane. Ćwiczenia laboratoryjne., pp. 48. Wydawnictwo Politechniki Częstochowskiej. 